\title{
Old-Age Trajectories of Life Satisfaction. Do Singlehood and Childlessness Hurt More When People Get Older?
}

\author{
Małgorzata Mikucka*
}

Abstract: This paper analyses trajectories of life satisfaction among elderly people in various family situations and tests whether the disadvantage related to being single or childless increases (as predicted by cumulative (dis)advantage hypothesis) or reduces (consistently with age-as-leveler hypothesis) when people get older. The results show that the disadvantage of never married mothers grows with age, whereas the disadvantage of divorced people reduces with age. The study suggests that, in general, the increasing probability of ageing without close kin does not put at risk life satisfaction of elderly people.

Keywords: life satisfaction, cumulative (dis)advantage, age-as-leveler

\section{Trajectoires de satisfaction de la vie des personnes âgées. Le célibat et l'infécondité font-ils plus mal à la vieillesse plus avancée?}

Résumé: Cet article analyse les trajectoires de satisfaction de la vie des personnes âgées dans diverses situations familiales et teste si le désavantage lié au fait d'être célibataire ou sans enfant augmente (comme le prédit l'hypothèse cumulative avantage) ou diminue (conformément à l'hypothèse de l'âge en tant que niveleur) lorsque les gens ont vieilli. Les résultats montrent que le désavantage des mères jamais mariées augmente avec l'âge, tandis que le désavantage des personnes divorcées diminue avec l'âge. L'étude suggère que, en général, la probabilité croissante de vieillir sans proches parents ne constitue pas un risque particulier pour la satisfaction de la vie des personnes âgées.

Mot-clés: satisfaction à l'égard de la vie, (dis)avantage cumulatif, âge en tant que niveleur

\section{Altersverläufe der Lebenszufriedenheit. Verletzen Alleinsein und Kinderlosigkeit im fortgeschrittenen Alter mehr?}

Zusammenfassung: Dieser Aufsatz analysiert die Lebenszufriedenheit älterer Menschen in verschiedenen Familiensituationen und prüft, ob der Nachteil in Bezug auf Alleinstehende oder Kinderlose zunimmt (wie durch die kumulative Vorteilshypothese vorhergesagt) oder abnimmt (konsistent mit der Age-as-Leveler-Hypothese), wenn Leute älter werden. Die Ergebnisse zeigen, dass der Nachteil von nie verheirateten Müttern mit dem Alter zunimmt, während der Nachteil von geschiedenen Menschen mit dem Alter abnimmt. Die Studie legt nahe, dass die zunehmende Wahrscheinlichkeit des Älterwerdens ohne nahe Verwandte im Allgemeinen kein besonderes Risiko für die Lebenszufriedenheit älterer Menschen darstellt. Schlüsselwörter: Lebenszufriedenheit, kumulativer Vorteil, Age-as-Leveler-Hypothese 
European populations are ageing. Over the coming 50 years, due to increasing life expectancy, low fertility, and low immigration, population of people aged 65 or older in EU countries is expected to increase by almost one third, whereas the working-age population would decline in absolute (European Union 2018). Family patterns are changing too. Childlessness reached levels of about 20\% in some European regions, and continues to grow in others (Kreyenfeld and Konietzka 2017; Miettinen et al. 2015). With marriages rates decreasing and growing divorce rates, life-long marriage becomes a story of the past. As a consequence, the share of older adults without close kin (i. e. childless and unmarried) will likely increase in the future. The limited kin networks may reduce social support available to the elderly, with potentially negative consequences for their life satisfaction. The shortages of family support may create a vacuum which will burden welfare systems, putting forward life satisfaction of the older population as one of the most important societal challenges.

Past research studied life satisfaction differences between married and single elderly, and between parents and childless people (e.g., Albertini and Mencarini 2014; Berg et al. 2006; Dykstra and Hagestad 2007; 2016). We know that old-age singlehood is typically associated with lower life satisfaction and that childlessness creates disadvantage in some groups, mainly among the previously married (Dykstra 2009). However, the question whether the disadvantage of elderly without close kin worsens or attenuates as they are getting older has not been tackled by past studies.

This paper contributes to fill this gap by studying the dynamics of life satisfaction (defined as a global evaluative judgement about one's life, see: Kim-Prieto et al. 2005) among people aged 60 to 89 in Switzerland. The starting point of my analysis is to test whether family situation correlates with life satisfaction among the elderly. However, my main goal is to check whether the gaps between more satisfied and less satisfied groups widen or narrow down as people get older.

For the purpose of this paper, I define family situation as an intersection of parenthood and marital status. I distinguish between parents and childless people, and between married, never married, divorced, and widowed elderly. This definition requires two additional comments. First, I consider widowed, divorced, and never married people separately, although all these groups have no marital partner. I do this because past research showed different ageing patterns (Koropeckyj-Cox 1998) and different consequences of childlessness among previously married and never married people (Dykstra and Wagner 2007). Past studies demonstrated also that life satisfaction trajectories following divorce differed from those which followed widowhood (Frijters et al. 2011). The second comment pertains to the fact that in the analysis I focus on marital rather than on partnership status. The theoretical rationale of this decision is the greater, on average, stability of marital than nonmarital unions. I discuss this issue in more detail in section 2.2.1. 
Theoretically, two mechanisms may shape the shifts associated with ageing (Ferraro and Wilkinson 2013). According to cumulative (dis)advantage hypothesis, mid-life differences widen with age due to longer accumulation of positive (or negative) influences of one's resources and living environment (Dannefer 2003). Alternatively, according to age-as-leveler hypothesis, the mid-life differences narrow down with age, because resources and living conditions lose their importance when biological frailty and health problems come to the first plan. The goal of this article is to provide the first test of whether life satisfaction differences associated with family situation widen or narrow down as people get older. In other words, I test whether singlehood and childlessness become a greater disadvantage as people move towards more advanced old age.

\section{Background and past research}

\subsection{Family situation and life satisfaction}

Married people are in general more satisfied with their lives than the unmarried. Part of the effect is causal. Married couples have an economic advantage over unmarried people (Killewald 2013) due to economic specialization (Becker 1998) and marital wage premium of men (Ludwig and Brüderl 2018). Marriage is also a source of social and psychological resources: it gives people a sense of belonging, being important, loved, and valued (Musick and Bumpass 2012) and connects them with social networks that provide instrumental help, information, and advice (Thoits 2011). Selection also plays a role: happier singles are more likely to marry than the unhappy ones, and people who eventually divorce tend to be less happy already before getting married (Stutzer and Frey 2006). Just as marriage benefits life satisfaction, marital dissolution reduces life satisfaction, and widowhood and divorce are among the events most negatively affecting life satisfaction (e. g., Frijters et al. 2011).

These patterns hold also in the old age. Lifelong marriage seems particularly beneficial for life satisfaction, which, consistently with cumulative (dis)advantage mechanism, suggests that old age differences are greater than differences during midlife (e.g., Wilmoth and Koso 2002). Empirical studies showed that widowed and divorced elderly tended to suffer from more depressive symptoms than the married (Bures et al. 2009; Koropeckyj-Cox 1998), and the transition to widowhood correlates with a decline in life satisfaction (Chipperfield and Havens 2001). However, the positive effect of marriage is less clear-cut compared to the never married. Elderly who did not form a family of their own, i. e. those who never married and remained childless, declare similar levels of depression as their married counterparts (Koropeckyj-Cox 1998). 
Economic models of parenthood postulate that adult children are a source of pragmatic support for elderly people. Embodying the same idea, legal systems formulate maintenance obligations between adults and their parents (Dykstra and Hagestad 2016). However, in Western welfare states, the elderly satisfy their everyday needs with the help of their pensions, health care system, and social services rather than with the help of their adult children. The intergenerational exchange is dominated by downward (i. e. from parents to children) transfers of both financial resources and care (Bernard et al. 2001). Although the downward flow decreases as parents get older, even those aged 70 or more remain net givers (Albertini et al. 2007). Despite this, literature showed that elderly parents are more satisfied with their lives than the childless (Albertini and Arpino 2018), although the relationship varies across social contexts (Dykstra and Wagner 2007; Hansen et al. 2009).

\subsection{Age-related dynamics}

Dynamics of life satisfaction in the old age is a disputed topic. Part of research demonstrated a U-shaped trajectory, with life satisfaction reaching the lifetime minimum between the ages of 35 and 50, and increasing afterwards (Blanchflower and Oswald 2008). Other studies showed a pattern of increasing life satisfaction at the entry to old age (around the age of 60, see Frijters and Beatton 2012) followed by a decline at more advanced age (after the age of 75 according to Frijters and Beatton 2012; after the age of 65 according to Chen 2001 and Gwozdz and SousaPoza 2010). Still other studies documented stability of life satisfaction during old age (Gwozdz and Sousa-Poza 2010; Kunzmann et al. 2000; McAdams et al. 2012; Von Dem Knesebeck et al. 2007), a decline limited to women (Chipperfield and Havens 2001), or a decline limited to a few years preceding respondent's own death (Gerstorf et al. 2008).

It is an open question whether the relative advantage or disadvantage related to family situation remains stable, increases, or declines as people get older. Inequality literature proposed two alternative hypotheses: cumulative (dis)advantage hypothesis, which postulates that inequalities intensify with age, and age-as-leveler hypothesis, according to which inequalities among groups reduce with age (Ferraro and Wilkinson 2013). Below, I discuss them in more detail.

\subsubsection{Cumulative (dis)advantage hypothesis}

The cumulative (dis)advantage hypothesis postulates that the positive influence of (economic, social, or other) resources on life satisfaction accumulates from an early age throughout the life course (Dannefer 2003). As a result of longer accumulation period, the differences among groups tend to be greater during old age than during young age. This idea has been originally proposed by Merton (1968) as so-called "Matthew effect" to explain the increasing inequalities in academic success among scholars, but it has been used ever since to explore various topics, such as income 
inequality and employment (e.g., Pavlova and Silbereisen 2012). Consistently with cumulative (dis)advantage mechanism, research showed that health differences across educational and income groups intensify with age (Kim and Durden 2007), and that life satisfaction differences between employed and unemployed are greater at older ages than at younger ages (Pavlova and Silbereisen 2012).

Marriage, especially a long lasting marriage, and parenthood, which in principle is a long-term relationship, provide elderly with various types of resources. Married people have typically greater economic resources and are at a lower risk of poverty (Killewald 2013), whereas both marriage and parenthood may be sources of (emotional and instrumental) support and psychological benefits (Musick and Bumpass 2012). Indisputably, economic advantage, and social and psychological resources apply not only to marriage but also to non-marital partnerships. However, marriage may be particularly beneficial due to typically long-term character of the arrangement, higher on average quality of relationship (Umberson et al. 2006), and connection with a network of kin (Musick and Bumpass 2012).

Cumulative (dis)advantage hypothesis implies that resources are increasingly strong determinants of life satisfaction as people get older. This leads to the first hypothesis to be tested in current analysis, namely that life satisfaction advantage related to marriage and parenthood increases with age. In other words, I expect that the groups disadvantaged in terms of life satisfaction, such as, plausibly, the previously married and the childless, experience faster decline of life satisfaction with age than other groups.

\subsubsection{Age-as-leveler hypothesis}

The age-as-leveler hypothesis conceptualizes old age as a period of biological frailty, when everybody faces similar challenges related mainly to loss of health and perspective of own death. For this reason, at advanced old age resources (social, economic, or others) lose their importance as predictors of life satisfaction (Kim and Durden 2007). In part, the leveling related to ageing is caused also by selective mortality, which is higher among people with poorer health and with lower life satisfaction (e. g., Koivumaa-Honkanen et al. 2000).

Supporting the idea of levelling effect of ageing, research on "happiness equation" showed that own health becomes an increasingly important predictor of life satisfaction as people get older, and that variance of quality of life reduces with age (Motel-Klingebiel et al. 2004). In general, the age-as-leveler hypothesis found considerable support in research on educational differences in health (Dupre 2007), but it has not yet been verified for differences related to family situation.

Relevant for the age-as-leveler hypothesis is the distinction between third and fourth age, or between the "young old" and "oldest old". The age boundary between these two groups depends on social context, but usually it is marked at the age of 75, 80, or 85 years (Neugarten 1974; Smith and Ryan 2016). The young old reap 
the benefits of extending life expectancy. They are young enough to enjoy good health, tend to be affluent, well educated, and satisfied with their lives (Baltes and Smith 2003; Neugarten 1974). In terms of family situation, they are predominantly still married and living with a spouse, with children moving out of parental household. In contrast to that, the experience of the oldest old is marked by fragility, vulnerability, and unpredictability (Baltes and Smith 2003). This is the group who experiences transitions to widowhood more often, suffers from health decline, and is at increased risk of poverty.

As age-as-leveler hypothesis refers to frailty and poor health, it should affect life satisfaction of the oldest old, but not of the young old. This leads to the second hypothesis tested in the current paper: among the oldest old, but not among the young old, life satisfaction differences related to family situation reduce due to increasing frailty and health problems. In other words, groups disadvantaged in terms of life satisfaction experience slower erosion of life satisfaction, leading to (at least partial) catching up.

\subsection{Gender differences}

Roles of men and women within marriage are different, especially in older cohorts. It is therefore not surprising that marital status and its changes affect men and women differently (Chipperfield and Havens 2001). First, although in the cohorts born at the beginning of the twentieth century childlessness was related to economic disadvantage, in younger cohorts women who did not form a family of their own tend to be a privileged group. They stand out with higher education, better financial situation, and higher social activity (e.g. doing more volunteer work) than otherwise comparable wives and mothers (Cwikel et al. 2006; Dykstra 2009; Dykstra and Hagestad 2016). A similar pattern does not show up among men. Second, parenthood seems more important for women's than men's life satisfaction, as childless women are consistently less satisfied with their lives than mothers (Hansen et al. 2009). Third, marital status seems to play a greater role for men's life satisfaction than for women's: men's life satisfaction reduces more upon losing a spouse, and it increases more in case of re-marriage (Berg et al. 2006; Chipperfield and Havens 2001).

Conceptual approaches proposed so far do not lead to clear predictions on gender differences of old age dynamics of life satisfaction. Nonetheless, gender seems a potentially important factor. For this reason, I analyse life satisfaction of men and women separately to explore gender differences in old age dynamics of life satisfaction.

\subsection{Context of Switzerland}

Switzerland is an example of an ageing society, where high life expectancy and low birth rates put a pressure on the welfare system (Gabriel et al. 2015). Nonetheless, Switzerland not only enjoys one of the highest levels of life satisfaction among OECD countries (OECD 2019) but also it has been designated as the best place 
in the world to grow old (2015 Global AgeWatch Index, see Barry et al. 2015). Good economic conditions definitely contribute to that; consistently, poverty rates among Swiss elderly are relatively low (10\%-20\% according to Gabriel et al. 2015).

The statutory retirement age in Switzerland is 64 years for women and 65 years for men, but earlier and later retirement is possible. In the Swiss Household Panel data, among women aged 63 only $30 \%$ are retired, $53 \%$ at the age of 64 , and $68 \%$ at the age of 65 . Respective percentages are similar among men (34\% at the age of $64,60 \%$ at the age of 65 , and $73 \%$ at the age of 66 ). Almost all (i. e. over 95\%) women are retired at the age of 73 , and almost all men at the age of 77 years old. Transition to retirement is not a definitive end of working life, as $30 \%$ of all early retirees continue working after retirement (Dorn and Sousa-Poza 2005).

Patterns of family life in Switzerland may be considered traditional as far as births out of wedlock are concerned (Le Goff and Ryser 2010). However, the rate of childlessness is among the highest in the world, reaching the value of about $20 \%$ women in the youngest cohorts (Sobotka 2017). In current study sample, 13\% of men and $14-16 \%$ of women declared not having any children. Acceptance of childlessness in Switzerland is relatively high, and old-age dependence on children's help is an exception rather than the rule. Frail elderly people in Switzerland are rarely cared for by their adult children, and the share of "autonomous family type", comprising families where parents and adult children tend to live far away, have relatively little contact, and exchange relatively little support, is among the highest in Europe (42\% of parents aged 50 or older, see: Dykstra and Fokkema 2011).

\section{Data and methods}

\subsection{Data and sample}

This analysis used data from the Swiss Household Panel (SHP), a panel study initiated in 1999, which monitors social change in the population of Switzerland. The survey started with a stratified random sample of private households whose members represented the noninstitutionalised resident population in Switzerland (Voorpostel et al. 2018). To compensate for attrition of the initial sample, refreshment samples were added in 2004 and 2013. SHP follows the respondents and their children, and (since 2007) also respondents' cohabiting partners who have left the original household, until death or institutionalisation (Voorpostel et al. 2018). Data are collected via telephone interviews, but since 2010 also face-to-face and web modes have been offered to reluctant respondents. At the moment of writing this paper, 18 waves of SHP are available (1999-2017). However, data on life satisfaction have not been recorded in 1999, which limited the analysis to a maximum of 17 waves of observations. 
In order to account for dynamics of life satisfaction both among the young old and oldest old, I estimated models for two separate subsamples of men and women: those aged 60-74 and those aged 75-89. The first subsample (called subsequently "younger cohort") comprised people who have been observed at least once at the age of 60-64, and remained in the panel for at least 5 waves. The second subsample ("older cohort") comprised people who were observed at least once at the age of 75-79 years, and stayed in the panel for a minimum of 5 waves. In the analytical sample, the younger cohort comprised 723 men and 919 women (6083 and 7921 observations, respectively) and the older cohort comprised 255 men and 386 women (2021 and 3043 observations, respectively).

As challenges and potential gains related to family roles are typically different for men and women, I estimated separate models for men and women. Additional estimates, shown in Appendix A, tested the statistical significance of gender differences.

\subsection{Analytical approach}

This analysis focused on the dynamics of life satisfaction during old age. This called for a within-subject setup, such as fixed effects models. However, to understand the meaning of the changes occurring over time, the analysis must also account for the differences among groups at the beginning of the observation period. For this reason, current analysis relied on two types of models to study the relationship between family situation and dynamics of life satisfaction.

First, I used regular OLS regression to describe differences in life satisfaction among groups defined by their marital and parenthood status. I run this analysis on a sample containing only the initial observation for each respondent whom I subsequently included in the fixed effects analysis, i. e. on a sample of 60-64 year olds in case of the younger cohort and on a sample of 75-79 years olds in case of the older cohort.

Second, I used regression with individual fixed intercepts in order to study how life satisfaction changed as people got older, and whether the dynamics varied according to marital and parenthood status. Fixed effects regression controls for all observed and unobserved time-invariant differences among people, including personality traits, genetic factors, etc. (Allison, 2009), and models only the withinsubject changes of the dependent variable.

\subsection{Variables}

The dependent variable was self-reported general satisfaction with life, measured on a scale from 0 to 10 . In the SHP life satisfaction was assessed with the question "In general, how satisfied are you with your life if 0 means 'not at all satisfied' and 10 means 'completely satisfied'?". The variable approximated a normal distribution, was negatively skewed, and peaked at the value of 8 , which was both its overall mean and the median. 


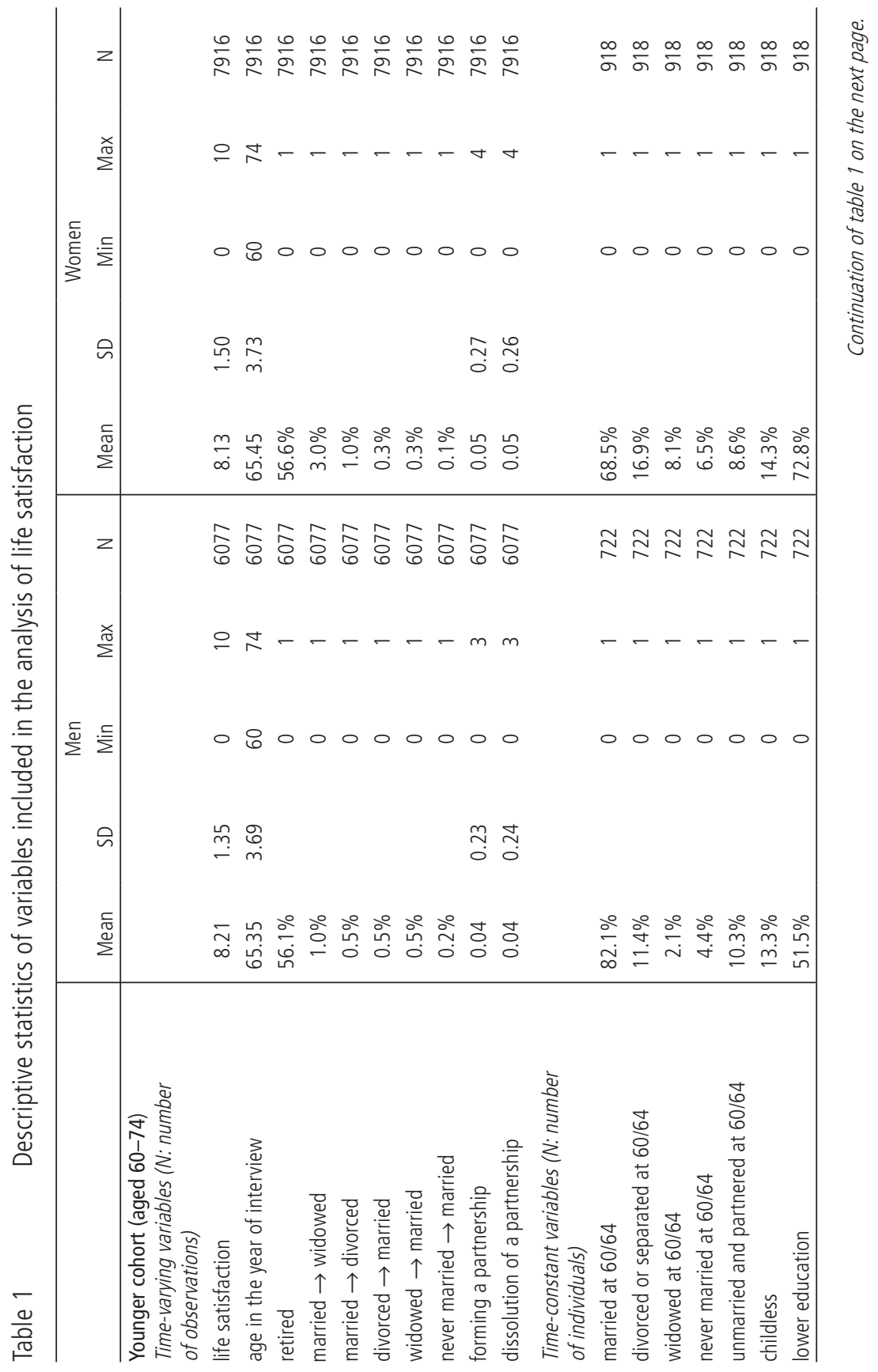




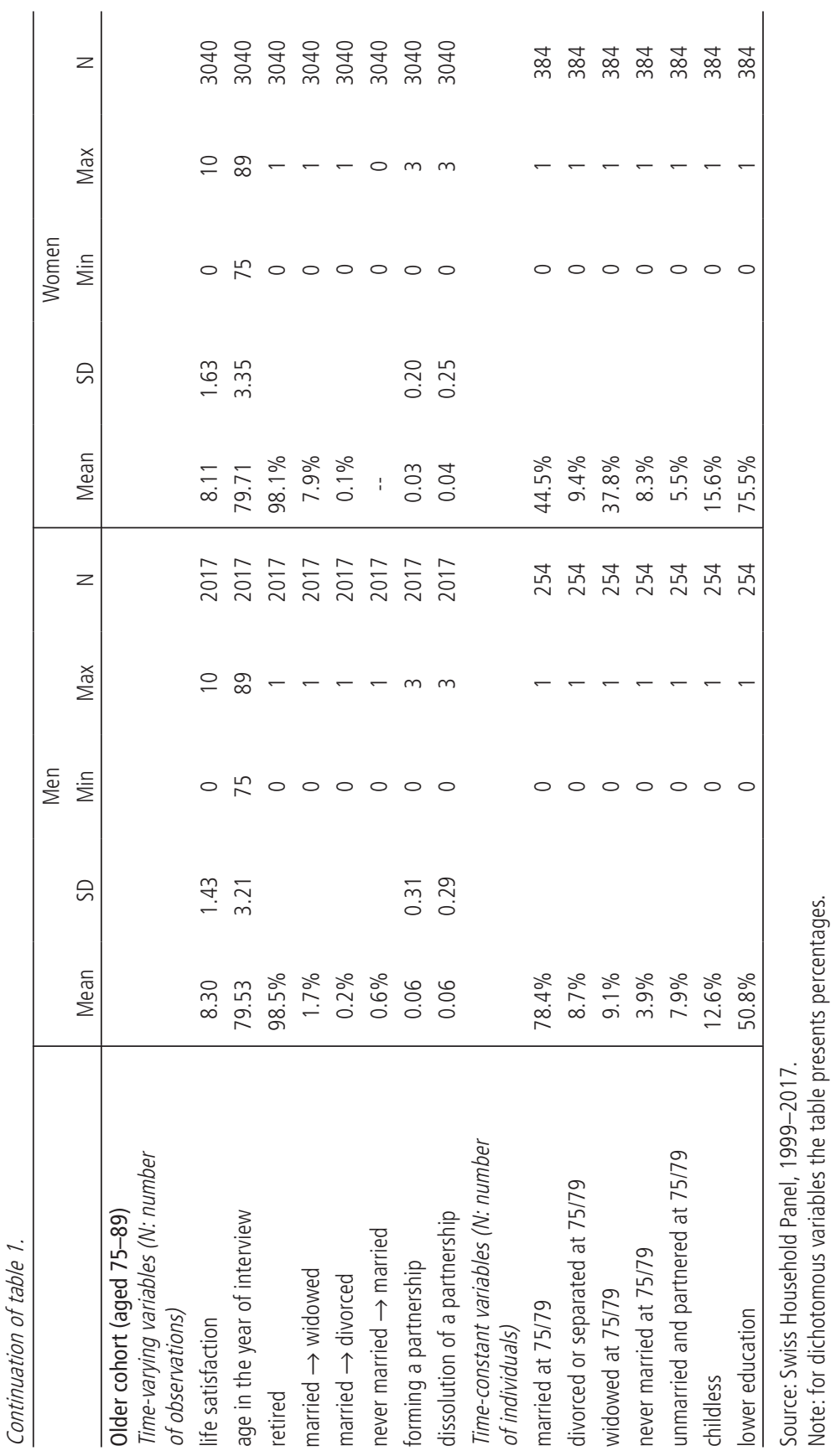


The OLS regression analysis aimed to describe the differences among men and women in various family situations. Accordingly, the main predictors were variables coding marital and parenthood status at the moment of the first observation. As parenthood and marital histories are closely interwoven (e.g. marriage is a strong predictor of parenthood), and the effects of marital and partnership status are typically not additive, I considered the effects of parenthood and marital status jointly, by including interaction terms. I also accounted for partnership status of unmarried respondents: the dichotomous variable coded as one people who had a partner, either cohabiting or not, and as zero it coded unpartnered persons. The control variables in the OLS model included education (primary vs. secondary of tertiary) and retirement status. ${ }^{1}$

The fixed effects analysis focused on age-related dynamics of life satisfaction among people in various family situations. Therefore, the main predictor was age, together with the interactions between age and the initial family situation (initial, i. e. recorded during the first interview for a given respondent at the age of 60-64 or 75-79). I also controlled for changes of marital status and partnership status experienced during the observation period, as well as the transition to retirement. ${ }^{2}$ All variables used in the analysis are summarized in Table 1. As shown in the table, marital transitions were relatively rare in the studied sample. For example, the transition from marriage to widowhood was the most common type of transition among women in the younger cohort, and it was recorded only in 3\% of observations. In the older cohort it raised to $8 \%$ of observations. Despite the rare character of these transitions, they are potentially powerful predictors of life satisfaction shifts.

\section{Results}

Table 2 shows the results of OLS regression of life satisfaction at the beginning of the observation period. In general, life satisfaction differed according to marital status. Married (the reference category) stood out as the most satisfied group among the parents. Divorced and widowed parents were less satisfied with their lives than the married; the difference was statistically significant in the younger cohort, and - in case of divorced - also among men in the older cohort. Moreover, never married mothers declared lower life satisfaction than married mothers, but, again, the difference was statistically significant only in the younger cohort. Among unmarried respondents, the partnered were more satisfied with their lives than the unpartnered, and the difference was statistically significant only in the younger cohort.

1 In Switzerland it is possible to combine retirement with employment, therefore as the transition to retirement I consider the first such transition declared by a respondent.

2 Formation and dissolution of a partnership is expressed as a count. Each respondent, at the beginning of observation, starts with a count of zero. The count increases by one at each partnership being formed or dissolved. 
Table 2

Life satisfaction at the beginning of observation period as a function of family situation. OLS models

\begin{tabular}{|c|c|c|c|c|c|c|c|c|}
\hline & \multicolumn{4}{|c|}{ Men } & \multicolumn{4}{|c|}{ Women } \\
\hline & \multirow{2}{*}{\multicolumn{2}{|c|}{$\begin{array}{c}\text { Age 60/64 } \\
\text { FE }\end{array}$}} & \multirow{2}{*}{\multicolumn{2}{|c|}{$\begin{array}{l}\text { Age } 75 / 79 \\
\text { SD }\end{array}$}} & \multirow{2}{*}{\multicolumn{2}{|c|}{$\begin{array}{c}\text { Age } 60 / 64 \\
\text { FD }\end{array}$}} & \multirow{2}{*}{\multicolumn{2}{|c|}{$\begin{array}{l}\text { Age } 75 / 79 \\
\text { SD }\end{array}$}} \\
\hline & & & & & & & & \\
\hline divorced (ref: married) & $-0.88^{* * *}$ & $(0.24)$ & $-0.74^{*}$ & $(0.33)$ & $-1.20^{\star * *}$ & $(0.16)$ & -0.29 & $(0.34)$ \\
\hline widowed (ref: married) & $-1.65^{* * *}$ & $(0.40)$ & -0.22 & $(0.36)$ & $-0.86^{* * *}$ & $(0.20)$ & -0.14 & $(0.21)$ \\
\hline never married (ref: married) & -0.35 & $(1.03)$ & -0.05 & $(1.42)$ & $-2.35^{* * *}$ & $(0.52)$ & -0.35 & $(1.76)$ \\
\hline $\begin{array}{l}\text { unmarried and partnered } \\
\text { (ref: unpartnered) }\end{array}$ & $0.63^{*}$ & $(0.26)$ & 0.54 & $(0.40)$ & $1.04^{* * *}$ & $(0.20)$ & -0.57 & (0.40) \\
\hline childless & 0.19 & $(0.21)$ & 0.39 & $(0.35)$ & 0.01 & $(0.22)$ & 0.08 & $(0.60)$ \\
\hline divorced $\times$ childless & 0.45 & $(0.45)$ & -0.71 & $(1.46)$ & 0.25 & $(0.44)$ & 0.72 & $(1.10)$ \\
\hline widowed $x$ childless & 2.72 & (1.49) & -0.06 & $(0.77)$ & -0.84 & $(0.65)$ & -0.50 & $(0.76)$ \\
\hline never married $\times$ childless & -0.74 & (1.06) & -0.82 & (1.49) & 1.18 & $(0.60)$ & 0.26 & $(1.88)$ \\
\hline retired & $0.29^{*}$ & $(0.14)$ & -0.21 & $(0.62)$ & $0.40^{* *}$ & $(0.13)$ & 0.24 & $(0.50)$ \\
\hline lower education & $-0.22^{*}$ & $(0.11)$ & -0.05 & $(0.18)$ & 0.04 & $(0.11)$ & -0.14 & $(0.21)$ \\
\hline intercept & $8.33^{* * *}$ & $(0.08)$ & $8.72^{\star \star \star}$ & $(0.61)$ & $8.39 * * *$ & $(0.11)$ & $8.11^{* * *}$ & $(0.51)$ \\
\hline N & 7. & & & & 91 & & 38 & \\
\hline
\end{tabular}

Source: Swiss Household Panel, 1999-2017.

Childlessness, on the other hand, did not correlate (statistically significantly) with life satisfaction. Childless people did not differ in their life satisfaction from parents neither among the married (see the main effect of childlessness) nor among divorced, widowed, or never married people (see the interaction terms).

To verify the cumulative (dis)advantage and age-as-leveler hypotheses let's inspect the results of fixed effects analysis (see Table 3). The age coefficients inform how much life satisfaction of married parents (who are the reference group) changed as people were getting older. All the age coefficients were negative, but they did not reach statistical significance. The predicted tempo of decline was rather small: about 0.02 points on a scale from 0 to 10 yearly. At this rate reducing life satisfaction by 1 point would require about 50 years.

The first hypothesis, which referred to the cumulative (dis)advantage mechanism, postulated that the initial differences in life satisfaction increase with age. OLS results showed that in the younger cohort the most satisfied group were married parents, thus, if the hypothesis holds, this group should have more positive trajectories of life satisfaction than other groups. In other words, life satisfaction of divorced, married, or never married should decline with age at a faster rate than life satisfaction of the married.

Relevant for testing this hypothesis are the interaction terms between marital status and age. Contrary to the predictions of the cumulative (dis)advantage hypothesis, divorced, widowed, and never married did not have more negative trajectories of life satisfaction than the married. Even more, life satisfaction trajectories of divorced 
and never married mothers in younger cohort and divorced childless men in older cohort were more positive than those of the married.

In the OLS analysis, the least satisfied group were never married mothers; this result was statistically significant only in the younger cohort. Fixed effects analysis showed that in the older cohort life satisfaction of never married mothers declined at a significantly faster rate than life satisfaction of married mothers. This suggests that never married mothers experienced both low initial life satisfaction and a disproportionally fast decline of life satisfaction. Such pattern is in principle consistent with the cumulative advantage hypothesis. However, the support for the hypothesis is only partial, because these two patterns were observed in different cohorts, and in none of the cohorts both patterns showed up.

The second, age-as-leveler hypothesis postulated that old age is a period of reducing inequalities. This implies that people in family situations associated with highest life satisfaction should experience a relatively faster decline of life satisfaction with age. On the other hand, in groups less satisfied with their lives during midlife, life satisfaction should decline at a slower rate. The hypothesis postulated that the main factors which reduce inequalities are health decline and frailty occurring in advanced old age; for this reason I expected to find these patterns mainly in the older cohort.

The results partially support the age-as-leveler hypothesis for divorced men only. In the OLS analysis, life satisfaction of divorced men in older cohort was lower than life satisfaction of married men. Fixed effects analysis showed that life satisfaction of divorced childless men in the older cohort increased disproportionally fast. However, the support for age-as-leveler hypothesis was only partial, because the fast increase occurred only for the childless, and not for all divorced men.

Results showed in Table 3 also inform that being in a partnership did not affect life satisfaction trajectories during old age. All the coefficients "in nonmarital partnership $\times$ age" were statistically not significant. Also lower educated people did not differ in their life satisfaction trajectories from people with secondary or tertiary education.

Consistently with the literature, formation of a partnership correlated with an increase in life satisfaction, whereas a dissolution correlated with a decline of life satisfaction. However, the results were statistically significant only in the younger cohort. The effects of marital transitions were less clear-cut. Transitions to widowhood and divorce correlated with reduction of life satisfaction, but not among women in the older cohort. Similarly, the old-age transitions into marriage did not have a consistently positive effect.

Coefficients for marital transitions allow investigating the protective role of parenthood. The first interesting result pertains to men who experienced a transition to widowhood. The negative effect of this transition was stronger among childless men than among fathers. This result is consistent with past evidence showing that 


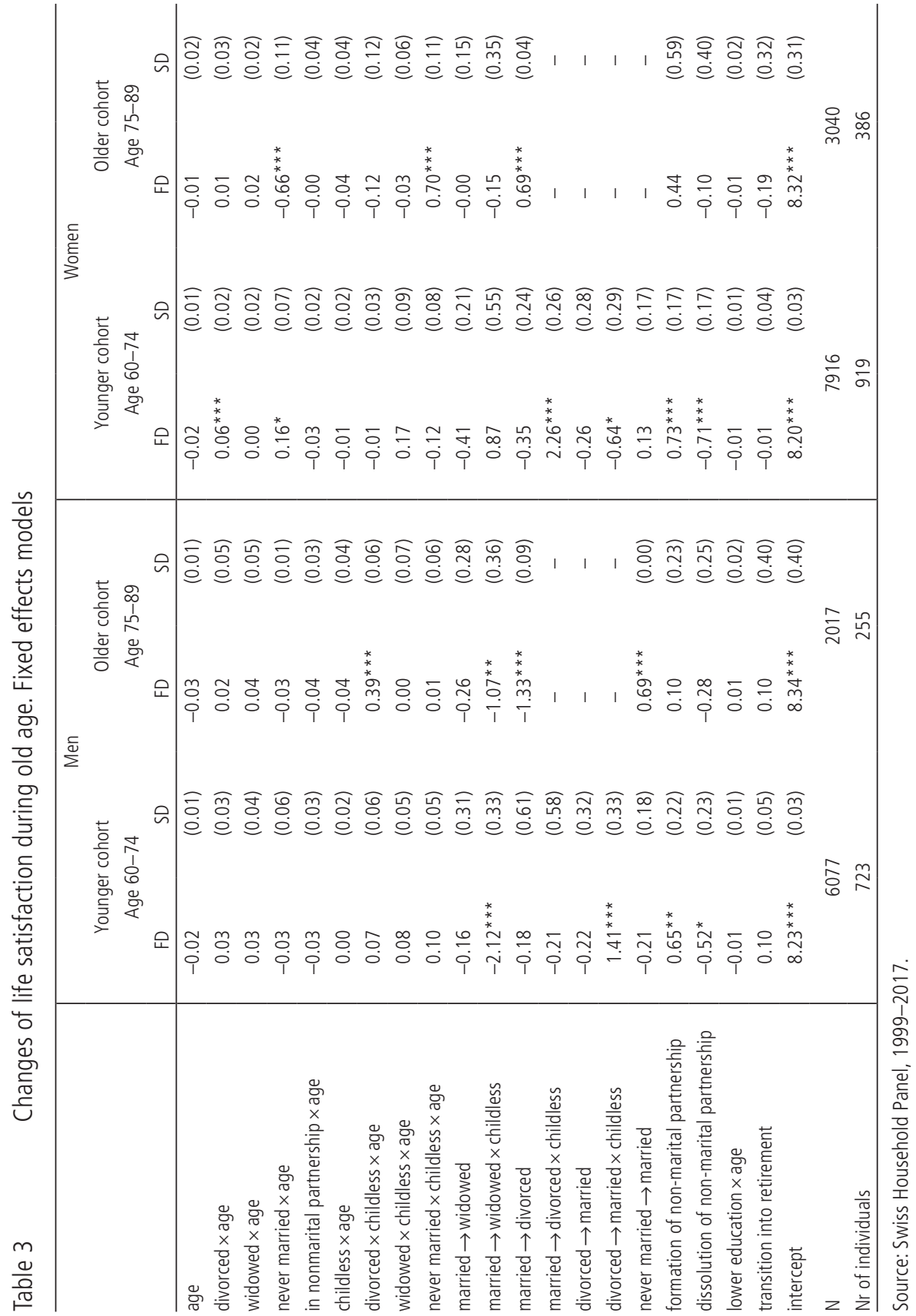


Figure $1 \quad$ Predicted life satisfaction and its changes: differences related to marital status
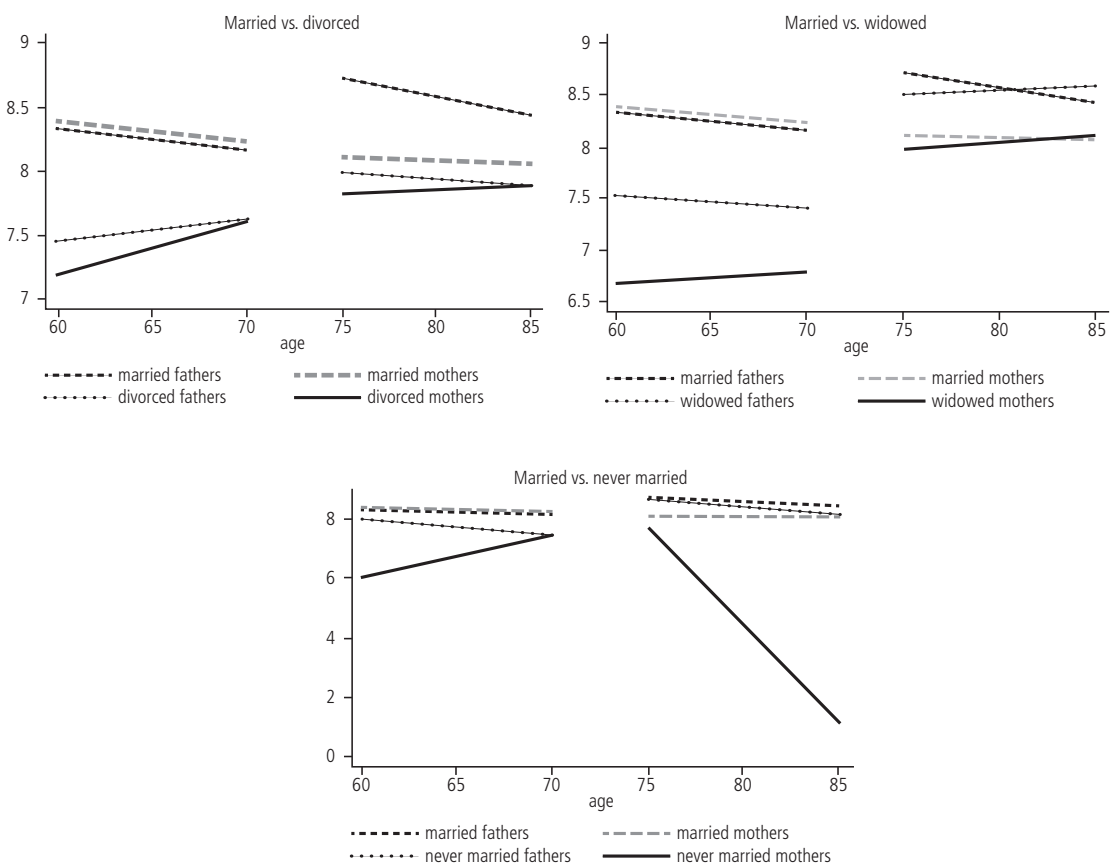

Source: Swiss Household Panel, 1999-2017 Note: The predictions combine the results obtained in the OLS models (Table 2) and in fixed effects models (Table 3.)

widowed men strongly depend on their adult children, and suggests that parenthood has a protective (buffering) effect during the transition to widowhood; however, it also suggests that this protection is limited to men. In contrast to that, divorce correlated with more positive shifts of life satisfaction among childless women than among mothers. This suggests that the protective effect of parenthood is not a general pattern, and that during divorce parenthood may be an additional source of stress rather than a resource.

Figures 1 and 2 provide a graphic representation of the results obtained in OLS and fixed effects analysis. Figure 1 shows how differences in life satisfaction related to marital status changed with age. The life satisfaction gap between divorced and married parents, and between widowed and married parents reduced with age, both among men and women, and in the younger and older cohort. In contrast to that, life satisfaction of never married parents, with the exception of never married mothers in the younger cohort, declined at a faster rate than among the married. 
Figure 2 Predicted life satisfaction and its changes: differences related to marital status
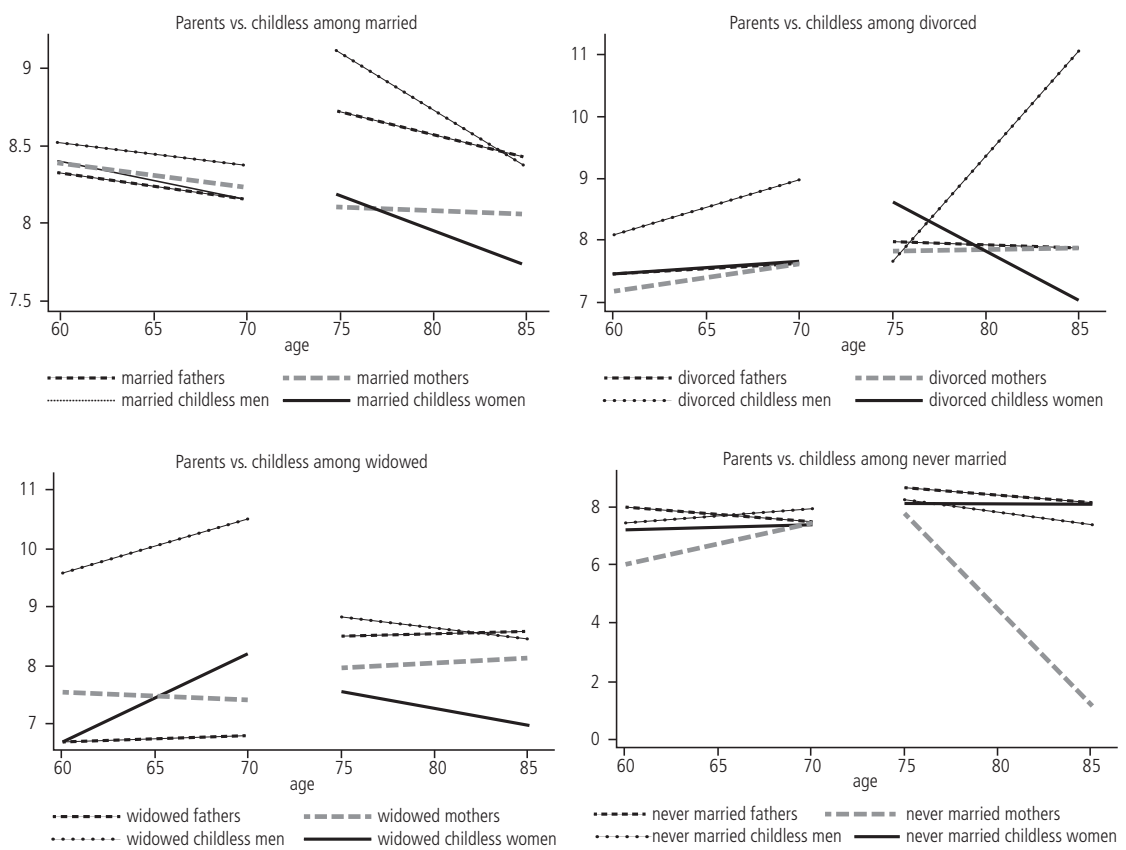

Source: Swiss Household Panel, 1999-2017 Note: The predictions combine the results obtained in the OLS models (Table 2) and in fixed effects models (Table 3.)

Figure 2 shows how childlessness affected life satisfaction trajectories of men and women in various marital statuses. An interesting pattern emerged for initially married respondents: in the older cohort, childless spouses experienced a visibly faster decline of life satisfaction than parents did. However, an inspection of results in Table 3 informs that the relevant coefficients ("childless $\times$ age") were not statistically significant. Also among the widowed the pattern was interesting. In the younger cohort, the life satisfaction trajectories of childless widowed persons were more positive than those of widowed parents. In contrast to that, in the older cohort life satisfaction trajectories of childless widowed persons were more negative than those of widowed parents. Summing up, childlessness among married and widowed persons negatively affected life satisfaction trajectories at more advanced old age. Such a pattern is not consistent with any of the hypotheses, but it suggests that parenthood protects life satisfaction in particular at advanced old age (in present analysis: after the age of 75). 
Among the divorced, the pattern was less clear. Childlessness correlated with more positive life satisfaction trajectories among divorced men, but with more negative life satisfaction trajectories among divorced women. This result may reflect gender difference in how divorce affects men's and women's relationships with children; in particular, it suggests that relationships with children may be an additional complication for elderly divorced men.

Finally, the predictions in Figure 2 for never married parents and never married childless people are dominated by the tremendous decline of life satisfaction experienced by never married mothers in the older cohort. This result suggests that never married mothers are a particularly disadvantaged group among the elderly.

Although the literature mentions gender differences in how family situation affects life satisfaction, current results showed an unclear pattern of gender differences and few statistically significant differences between men and women. The detailed table of results is shown in the Appendix in Table A4 (for the OLS analysis) and Table A5 for the fixed effects analysis.

The difference between men and women in the importance of parenthood, marital status or childlessness for life satisfaction and its changes was not systematic. The differences that did occur pertained to the effect of childlessness among divorced, widowed, and never married people. This suggests that, despite the gendered character of marriage, childlessness has different consequences among men and women not in marriage but rather outside of it.

\section{Discussion}

This paper studied the population of elderly people in Switzerland in order to better understand how the effect of family situation for life satisfaction changes during old age. I defined family situation by respondent's marital and parenthood status, and accounted for partnership status of unmarried respondents. The analysis tested whether unmarried and childless respondents were less satisfied with their lives than married people and parents, and whether the differences intensified or attenuated with age.

The results showed that in the cohort of people aged 60-64 years old, married persons were indeed more satisfied with their lives than singles, including never married, divorced, and widowed persons. However, the differences in the older cohort (75-79 years old) were statistically not significant. The result for the younger cohort is consistent with previous literature, which documented life satisfaction advantage of married people over the unmarried (e.g., Bures et al. 2009; Koropeckyj-Cox 1998). In contrast to marital status, childlessness did not systematically correlate with life satisfaction. This lack of differences is at odds with some past studies (e. g., Albertini and Arpino 2018) but may be explained by the cross-country variation of this relationship (Dykstra and Wagner 2007; Hansen et al. 2009). 
To understand whether the differences related to family situation intensify or reduce with age, I analysed within-individual changes of life satisfaction. Life satisfaction among married parents (who were the reference category in the analysis) has been declining slightly with age. Such result is at odds with studies showing clear pattern of age trajectories of life satisfaction (e.g., Blanchflower and Oswald 2008). The baseline rate of decline in current analysis did not differ systematically with gender nor education, but it was shaped by life course transitions. This suggests that, at least in the studied social context, life satisfaction trajectories are shaped by the events that people experience, rather than by their underlying characteristics.

I tested two competing hypotheses. The first one, cumulative (dis)advantage hypothesis postulated that, due to longer exposure to advantageous conditions, the differences among groups intensify with age (Dannefer 2003). In current analysis, the group experiencing most "advantageous conditions" were the married parents, judging from their initial life satisfaction at the age of 60-64 years old. On the other hand, the group with lowest life satisfaction at the same ages were the never married mothers.

The hypothesis predicted that life satisfaction trajectories of married parents should be more positive than life satisfaction of the divorced, widowed, or never married. However, the results did not show this pattern. On the contrary, life satisfaction of some subgroups of unmarried respondents increased at a faster rate than life satisfaction of the married. This result suggests that the life satisfaction advantage of married parents over other groups does not result from a causal mechanism (which could continue shaping life satisfaction during an old age thus increasing the advantage of this group) but it is either created during mid-life (e.g. due to lower on average stress levels) or results from selection on background characteristics. In other words, the result suggests that being married and having children at older age in Switzerland is not in itself beneficial for life satisfaction.

Partly consistent with the hypothesis of cumulative (dis)advantage was the pattern for never married mothers. This group initially stood out with low life satisfaction, and subsequently, after the age of 75, experienced a faster decline in life satisfaction than other groups. However, the support for the hypothesis was only partial because the initial life satisfaction disadvantage was observed in younger cohort only, whereas the faster rate of life satisfaction decline occurred only in the older cohort. In general, single parenthood is a difficult experience and single parents stand out with low life satisfaction (e.g., Meier et al. 2016). In this aspect, Switzerland is a rather conservative social context, therefore it is not surprising that elderly never married mothers declared lower life satisfaction and experienced its more rapid decline than other groups of women did. This might happen due to selection, i. e. because women less able to avoid non-marital childbearing likely suffered an underlying disadvantage (related to, e. g. personality traits, social background, experience of abuse), but the effect might also be causal, i. e. due to social 
exclusion and economic strains of single parenthood. All these factors might have contributed to a rapid decline in life satisfaction during an advanced old age among never married mothers, as observed in current analysis.

The second, age-as-leveler hypothesis stated that life satisfaction differences related to marital status reduce at advanced old age, because at this stage of life people experience frailty and health decline, and in the light of this experience other factors or resources lose their importance as determinants of life satisfaction. This hypothesis implied that advanced old age is a period of reducing inequalities, meaning that life satisfaction of initially advantaged groups should decline at a faster rate than life satisfaction of more disadvantaged groups.

The support for age-as-leveler hypothesis was only partial. First, in the younger cohort, life satisfaction of divorced mothers, who were disadvantaged already at the beginning of observation span, increased faster than life satisfaction of married mothers. However, this pattern showed up in the younger cohort only, whereas the hypothesis predicted that the leveling mechanism should play a role primarily at advanced old age. Second, life satisfaction of divorced childless men in older cohort increased faster than life satisfaction of married fathers; however, this "catching up" occurred only for childless divorced men, whereas all divorced men (fathers and childless alike) declared low life satisfaction at the beginning of observation span. The qualitative inspection of results (predictions shown in Figure 1) suggested that the life satisfaction gap between married and previously married people has been closing for both men and women, and both in younger and older cohorts. However, this general pattern did not reach statistical significance.

The fact that the leveling associated with ageing was statistically significant only in case of the gap between divorced and married respondents (and a similar pattern showed up for the gap between widowed and married), and that it was not limited to advanced old age, suggests that it was not shaped by ageing and emerging frailty but rather by adaptation to divorced (widowed) life. Upon divorce and widowhood, life satisfaction declines and then re-bounces (e.g., Frijters et al. 2011), which is interpreted as a sign of the psychological mechanism of adaptation. This mechanism might narrow down the life satisfaction gap between married and previously married respondents observed in the results. ${ }^{3}$

The results showed also interesting patterns which went beyond the tested hypotheses. First, the effects of marital transitions were less clear-cut than generally suggested by happiness literature (e.g., Frijters et al. 2011). Transitions to widowhood and divorce correlated with reduction of life satisfaction, but not among women in the older cohort. Similarly, the old-age transitions into marriage did not have consistently positive effect. A possible explanation of this pattern is the fact that

3 It is possible that the results for widowhood did not reach statistical significance, because the negative life satisfaction consequences of death of a spouse last longer than in case of divorce, and strategies of re-building one's life, such as re-partnering are less available in part due to more advanced old age of widows than divorcees. 
current analysis ignored the time which elapsed from the event, which may make a difference for these strongly time-dependent effects (Frijters et al. 2011).

The second interesting pattern pertained to non-marital partnerships. Partnership is a plausible source of social and economic resources, even if it is typically a shorter-term arrangement than marriage. In fact, partnered unmarried people were more satisfied with their lives than the unpartnered. Consistently, formation of a partnership correlated with an increase in life satisfaction, whereas a dissolution correlated with a life satisfaction decline. ${ }^{4}$ Finally, being in a partnership did not affect life satisfaction trajectories occurring with age, whereas marital status had such an affect, suggesting that the long-term effect of marriage may play a role.

As mentioned above, childlessness made little systematic difference for life satisfaction and its dynamics. However, in some groups parents clearly differed from childless persons. In particular, elderly men who became widowers experienced a greater loss of life satisfaction if they were also childless. Additionally, childless married and divorced respondents in the older cohort experienced a more rapid decline of life satisfaction than parents did. In contrast to that, the patterns among divorced people were less consistent, and childless women going through divorce experienced more positive shifts of life satisfaction than mothers going through a divorce.

This result suggests that even if parenthood has no direct effect on life satisfaction of elderly people, in some instances it has a protective buffering effect. This type of protection applies to married and widowed people, and is most visible among men entering widowhood. Switzerland stands among European countries with relatively low contact and support exchange between adult children and their elderly parents; this suggests that the buffering effect of parenthood and its effect on life satisfaction in other countries may be stronger. On the other hand, the buffering effect of parenthood did not extend to divorcing elderly people, suggesting that, instead of having a buffering effect, parenthood complicates the divorce experience even for spouses with adult children.

In general, current analysis revealed a considerable difference between people belonging to the younger and older cohort. In particular, very few factors consistently differentiated life satisfaction in the older cohort. This may reflect smaller sample size and lower power of statistical models in the analysis of the older cohort. However, the lower predictive power of models is also consistent with the idea of leveling effect of age. On the other hand, age-as-leveler mechanism also postulated that variation of life satisfaction in the older cohort should be smaller than in the younger cohort. The characteristics of the sample used in this analysis do not confirm that (as shown in Table 1 with descriptive statistics). It seems that in current analysis the life satisfaction differences among people aged 75-89 were considerable, but the statistical models were not able to explain them.

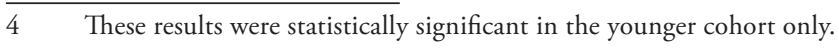


Current analysis explored also the differences between men and women. Gender seems a potentially important factor moderating the relationship between family situation and life satisfaction in Switzerland. Despite the relatively traditional gender roles, the results showed that marriage and parenthood affected life satisfaction of men and women in a similar fashion. The few gender differences recorded by this study reflected the relative disadvantage of never married mothers, and the greater salience of buffering effect of parenthood among men than among women.

This study has limitations. First, the SHP data did not allow a full picture of old-age life satisfaction changes, as the respondents in the analysed sample were observed on average for 10 years (between 5 and 14 years of observations). Such time span constitutes a relatively small fraction of old age in a developed ageing society as Switzerland. Similarly, current study did not include the worse functioning respondents, as only those living in individual households were included in the sample. Institutionalization, which frequently accompanies old age health decline, was one of the factors excluding respondents from the sample. Another limitation is that current analysis did not inspect mechanisms mediating the relationship between family situation and life satisfaction. Investigating the role of potentially important factors, such as social support, economic well-being, or health, is an interesting area for future studies.

Available results support the following conclusions. First, neither cumulative (dis)advantage hypothesis, nor age-as-leveler mechanism accurately describe how the importance of family situation for life satisfaction changes when people progress into advanced old age. Although some results of this analysis were consistent with the postulated patterns, the hypotheses do not seem to capture the core of the old age dynamics of life satisfaction. In contrast to that, buffering effect of parenthood and psychological adaptation after divorce or widowhood seem to capture more accurately the processes affecting life satisfaction during old age. The second conclusion is that life satisfaction of young old is better predicted by statistical models than life satisfaction of the oldest old. Further studies of this difference might address, among others, the issue of quality of data collected from oldest respondents. Finally, in practical terms, current analysis points to a particularly disadvantaged group of elderly, which has remained largely unnoticed by the happiness literature: never married mothers. Exploring specificity of this groups may be an interesting avenue for further research.

The take-home message from this research is that growing instability of marriages and increasing population of elderly without close kin does not pose a considerable threat for life satisfaction of elderly people in relatively wealthy countries which offer welfare support. The often implicit assumption that lack of close family is particularly painful and troublesome for elderly persons did not find consistent support in current analysis. 


\section{References}

Albertini, Marco and Bruno Arpino. 2018. Childlessness, parenthood and subjective wellbeing: The relevance of conceptualizing parenthood and childlessness as a continuum. Preprint.

Albertini, Marco, Martin Kohli and Claudia Vogel. 2007. Intergenerational transfers of time and money in European families: common patterns - different regimes? Journal of European Social Policy 17(4): 319-334.

Albertini, Marco. and Letizia Mencarini. 2014. Childlessness and support networks in later life. Journal of Family Issues 35(3): 331-357.

Allison, Paul D. 2009. Fixed effects regression models, Quantitative Applications in Social Sciences, Volume 160. Thousand Oaks: SAGE.

Baltes, Paul B., and Jacqui Smith. 2003. New frontiers in the future of aging: From successful aging of the young old to the dilemmas of the fourth age. Gerontology 49(2): 123-135.

Barry, Amy, Scarlett McGwire and Karen Porter (eds.). 2015. Global Age Watch Index 2015 Insight report. HelpAge International,

Becker, Garry S. 1998. A Treatise on the Family. Cambridge, MA: Harvard University Press.

Berg, Anne Ingeborg, Linda B. Hassing, Gerald E. McClearn, and Boo Johansson. 2006. What matters for life satisfaction in the oldest-old? Aging and Mental Health 10(3): 257-264.

Bernard, Miriam, Chris Phillipson, Judith Phillips, and Jim Ogg. 2001. Continuity and change in the family and community life of older people. Journal of Applied Gerontology 20(3): 259- 278.

Blanchflower, David G., and Andrew J. Oswald. 2008. Is well-being U-shaped over the life cycle? Social Science \& Medicine 66(8): 1733-1749.

Bures, Regina M., Tanya Koropeckyj-Cox, and Michael Loree. 2009. Childlessness, parenthood, and depressive symptoms among middle-aged and older adults. Journal of Family Issues 30(5): 670-687.

Chen, Chaonan. 2001. Aging and life satisfaction. Social Indicators Research 54(1): 57-79.

Chipperfield, Judith G., and Betty Havens. 2001. Gender differences in the relationship between marital status transitions and life satisfaction in later life. The Journals of Gerontology Series B: Psychological Sciences and Social Sciences 56(3): P176-P186.

Cwikel, Julie, Helen Gramotnev, and Christina Lee. 2006. Never-married childless women in Australia: Health and social circumstances in older age. Social Science \& Medicine 62(8): 1991-2001.

Dannefer, Dale. 2003. Cumulative advantage/disadvantage and the life course: Cross-fertilizing age and social science theory. The Journals of Gerontology Series B: Psychological Sciences and Social Sciences 58(6): S327-S337.

Dorn, David, and Alfonso Sousa-Poza. 2005. The determinants of early retirement in Switzerland. Swiss Journal of Economics and Statistics 141(2): 247-283.

Dupre, Matthew E. 2007. Educational differences in age-related patterns of disease: Reconsidering the cumulative disadvantage and age-as-leveler hypotheses. Journal of Health and Social Behavior 48(1): $1-15$.

Dykstra, Pearl A. 2009. Childless old age. In International Handbook of Population Aging, pages 671-690. Springer.

Dykstra, Pearl A., and Tineke Fokkema. 2011. Relationships between parents and their adult children: A West European typology of late-life families. Ageing \& Society 31(4): 545- 569.

Dykstra, Pearl A., and Gunhild O. Hagestad. 2007. Childlessness and parenthood in two centuries: different roads-different maps? Journal of Family Issues 28(11): 1518-1532.

Dykstra, Pearl A., and Gunhild O. Hagestad. 2016. Roads Less Taken. Journal of Family Issues 28(10): $1275-1310$. 
Dykstra, Pearl A., and Michael Wagner. 2007. Pathways to childlessness and late-life outcomes. Journal of Family Issues 28(11): 1487-1517.

European Union. 2018. The 2018 Ageing Report. Economic \& budgetary projections for the 28 EU Member States (2016-2070). European Economy Institutional Papers Institutional Paper 079, Publications Office of the European Union, Luxembourg.

Ferraro, Kenneth F., and Lindsay R. Wilkinson. 2013. Age, aging, and mental health. In Carol S. Aneshensel, Jo C. Phelan and Alex Bierman (eds.) Handbook of the Sociology of Mental Health. Second edition. Springer.

Frijters, Paul, and Tony Beatton. 2012. The mystery of the U-shaped relationship between happiness and age. Journal of Economic Behavior \& Organization 82(2-3): 525-542.

Frijters, Paul, David W. Johnston, and Michael A. Shields. 2011. Life satisfaction dynamics with quarterly life event data. Scandinavian Journal of Economics 113(1): 190-211.

Gabriel, Rainer, Michel Oris, Matthias Studer, and Marie Baeriswyl. 2015. The persistence of social stratification? A life course perspective on poverty in old-age in Switzerland. Revue Suisse de Sociologie 41(3): 465-487.

Gerstorf, Denis, Nilam Ram, Christina Röcke, Ulman Lindenberger, and Jacqui Smith. 2008. Decline in life satisfaction in old age: Longitudinal evidence for links to distance-to-death. Psychology and Aging 23(1): 154-168.

Gwozdz, Wencke, and Alfonso Sousa-Poza. 2010. Ageing, health and life satisfaction of the oldest old: An analysis for Germany. Social Indicators Research 97(3): 397-417.

Hansen, Thomas, Britt Slagsvold, and Torbjørn Moum. 2009. Childlessness and psychological wellbeing in midlife and old age: An examination of parental status effects across a range of outcomes. Social Indicators Research 94(2): 343-362.

Killewald, Alexandra. 2013. A reconsideration of the fatherhood premium: Marriage, coresidence, biology, and fathers' wages. American Sociological Review 78(1): 96-116.

Kim, Jinyoung, and Emily Durden. 2007. Socioeconomic status and age trajectories of health. Social Science \& Medicine 65(12): 2489-2502.

Kim-Prieto, Chu, Ed Diener, Maya Tamir, Christie Scollon, and Marissa Diener. Integrating the diverse definitions of happiness: A time-sequential framework of subjective well-being. Journal of Happiness Studies 6(3): 261-300.

Koivumaa-Honkanen, Heli, Risto Honkanen, Heimo Viinamäki, Kauko Heikkilä, Jaakko Kaprio, and Markku Koskenvuo. 2000. Self-reported life satisfaction and 20-year mortality in healthy Finnish adults. American Journal of Epidemiology 152(10): 983-991.

Koropeckyj-Cox, Tanya. 1998. Loneliness and depression in middle and old age: Are the childless more vulnerable? The Journals of Gerontology Series B: Psychological Sciences and Social Sciences 53(6): S303-S312.

Kreyenfeld, Michaela, and Dirk Konietzka (eds.). 2017. Childlessness in Europe: Contexts, causes, and consequences. Springer.

Kunzmann, Ute, Todd D. Little, and Jacqui Smith. 2000. Is age-related stability of subjective well-being a paradox? Cross-sectional and longitudinal evidence from the Berlin Aging Study. Psychology and Aging 15(3): 511-526.

Goff, Jean-Marie Le, and Valérie-Anne Ryser. 2010. Meaning of marriage for men during their transition to fatherhood: The Swiss context. Marriage \& Family Review 46(1-2): 107- 125.

Ludwig, Volker, and Josef Brüderl. 2018. Is there a male marital wage premium? New evidence from the United States. American Sociological Review 83(4): 744-770.

McAdams, Kimberly K., Richard E. Lucas, and M. Brent Donnellan. 2012. The role of domain satisfaction in explaining the paradoxical association between life satisfaction and age. Social Indicators Research 109(2): 295-303. 
Meier, Ann, Kelly Musick, Sarah Flood, and Rachel Dunifon. 2016. Mothering experiences: How single parenthood and employment structure the emotional valence of parenting. Demography 53(3): 649-674.

Merton, Robert K. 1968. The Matthew effect in science: The reward and communication systems of science are considered. Science 159(3810): 56-63.

Miettinen, Anneli, Anna Rotkirch, Ivett Szalma, Annalisa Donno, and Maria-Letizia Tanturri. 2015. Increasing childlessness in Europe: Time trends and country differences. Families and Societies. Working Paper Series, 3.

Motel-Klingebiel, Andreas, Hans-Joachim von Kondratowitz, and Clemens Tesch-Römer. 2004. Social inequality in the later life: cross-national comparison of quality of life. European Journal of Ageing 1(1): 6-14.

Musick, Kelly, and Larry Bumpass. 2012. Reexamining the case for marriage: Union formation and changes in well-being. Journal of Marriage and Family 74(1): 1-18.

Neugarten, Bernice L. 1974. Age groups in American society and the rise of the young-old. The Annals of the American Academy of Political and Social Science 415(1): 187-198.

OECD. 2019. Better Life index. Electronic database, OECD. Accessed on June 14, 2019.

Pavlova, Maria K., and Rainer K. Silbereisen. 2012. Age, cumulative (dis) advantage, and subjective well-being in employed and unemployed Germans: A moderated mediation model. Journal of Occupational Health Psychology 17(1): 93-104.

Smith, Jacqui, and Lindsay H. Ryan. 2016. Psychological vitality in the oldest old. In Handbook of the Psychology of Aging, pages 303-319. Elsevier.

Sobotka, Tomáš. 2017. Childlessness in Europe: Reconstructing long-term trends among women born in 1900-1972. In Childlessness in Europe: Contexts, causes, and consequences, pages 17-53. Springer.

Stutzer, Alois, and Bruno S. Frey. 2006. Does marriage make people happy, or do happy people get married? The Journal of Socio-Economics 35(2): 326-347.

Thoits, Peggy A. 2011. Mechanisms linking social ties and support to physical and mental health. Journal of Health and Social Behavior 52(2): 145-161.

Umberson, Debra, Kristi Williams, Daniel A. Powers, Hui Liu, and Belinda Needham. 2006. You make me sick: Marital quality and health over the life course. Journal of Health and Social Behavior 47(1): 1-16.

Von Dem Knesebeck, Olaf, Morten Wahrendorf, Martin Hyde, and Johannes Siegrist. 2007. Socioeconomic position and quality of life among older people in 10 European countries: Results of the SHARE study. Ageing \& Society 27(2): 269-284.

Voorpostel, Marieke, Robin Tillmann, Florence Lebert, Ursina Kuhn, Oliver Lipps, Valérie-Anne Ryser, Erika Antal, ,Gian-Andrea Monsch, Nora Dasoki and Boris Wernli. 2018. Swiss Household Panel User Guide (1999-2017). Wave 19. Technical report.

Wilmoth, Janet, and Gregor Koso. 2002. Does marital history matter? marital status and wealth outcomes among preretirement adults. Journal of Marriage and Family 64(1): 254-268. 


\section{Appendix: statistical significance of gender differences}

Table A4

Life satisfaction at the beginning of observation period as a function of family situation. OLS models with gender interaction terms

\begin{tabular}{|c|c|c|}
\hline & Age $60 / 64$ & Age $75 / 79$ \\
\hline woman & $\begin{array}{c}0.06 \\
(0.14)\end{array}$ & $\begin{array}{c}-0.61 \\
(0.86)\end{array}$ \\
\hline divorced at 60-64yo/75-79yo (ref: married) & $\begin{array}{l}-0.88^{* * *} \\
(0.25)\end{array}$ & $\begin{array}{c}-0.74 \\
(0.39)\end{array}$ \\
\hline divorced at 60-64yo/75-79yo × woman & $\begin{array}{c}-0.32 \\
(0.30)\end{array}$ & $\begin{array}{c}0.44 \\
(0.50)\end{array}$ \\
\hline widowed at 60-64yo/75-79yo (ref: married) & $\begin{array}{l}-1.65^{* * *} \\
(0.42)\end{array}$ & $\begin{array}{c}0.22 \\
(0.43)\end{array}$ \\
\hline widowed at 60-64yo/75-79yo × woman & $\begin{array}{c}0.79 \\
(0.46)\end{array}$ & $\begin{array}{c}0.07 \\
(0.47)\end{array}$ \\
\hline never married at 60-64yo/75-79yo (ref: married) & $\begin{array}{l}-0.35 \\
(1.09)\end{array}$ & $\begin{array}{c}-0.05 \\
(1.68)\end{array}$ \\
\hline never married at 60-64yo/75-79yo $\times$ woman & $\begin{array}{c}-2.00 \\
(1.20)\end{array}$ & $\begin{array}{c}-0.30 \\
(2.33)\end{array}$ \\
\hline unmarried and partnered (ref: unpartnered) & $\begin{array}{c}0.63^{*} \\
(0.27)\end{array}$ & $\begin{array}{c}0.54 \\
(0.47)\end{array}$ \\
\hline unmarried and partnered $\times$ woman & $\begin{array}{c}0.41 \\
(0.34)\end{array}$ & $\begin{array}{c}-1.11 \\
(0.60)\end{array}$ \\
\hline childless & $\begin{array}{c}0.19 \\
(0.22)\end{array}$ & $\begin{array}{c}0.39 \\
(0.41)\end{array}$ \\
\hline childless $\times$ woman & $\begin{array}{c}-0.18 \\
(0.31)\end{array}$ & $\begin{array}{c}-0.31 \\
(0.69)\end{array}$ \\
\hline divorced at 60-64yo/75-79yo $\times$ childless & $\begin{array}{c}0.45 \\
(0.47)\end{array}$ & $\begin{array}{c}-0.71 \\
(1.73)\end{array}$ \\
\hline divorced at 60-64yo/75-79yo $\times$ childless $\times$ woman & $\begin{array}{c}-0.19 \\
(0.63)\end{array}$ & $\begin{array}{c}1.43 \\
(2.00)\end{array}$ \\
\hline widowed at $60-64 \mathrm{yo} / 75-79 y o \times$ childless & $\begin{array}{c}2.72 \\
(1.56)\end{array}$ & $\begin{array}{c}-0.06 \\
(0.91)\end{array}$ \\
\hline widowed at $60-64 y 0 / 75-79 y o \times$ childless $\times$ woman & $\begin{array}{c}-3.56^{*} \\
(1.68)\end{array}$ & $\begin{array}{c}-0.44 \\
(1.14)\end{array}$ \\
\hline never married at 60-64yo/75-79yo $\times$ childless & $\begin{array}{c}-0.74 \\
(1.12)\end{array}$ & $\begin{array}{c}-0.82 \\
(1.76)\end{array}$ \\
\hline never married at 60-64yo/75-79yo $\times$ childless $\times$ woman & $\begin{array}{c}1.91 \\
(1.26)\end{array}$ & $\begin{array}{c}1.08 \\
(2.47)\end{array}$ \\
\hline
\end{tabular}




\section{Continuation of table A4.}

\begin{tabular}{l|c|c}
\hline & Age 60/64 & Age 75/79 \\
\hline retired & $0.29^{*}$ & -0.21 \\
& $(0.15)$ & $(0.74)$ \\
retired × woman & 0.10 & 0.45 \\
& $(0.20)$ & $(0.87)$ \\
lower education & $-0.22^{*}$ & -0.05 \\
lower education × woman & $(0.11)$ & $(0.21)$ \\
intercept & 0.26 & -0.10 \\
& $(0.16)$ & $(0.29)$ \\
$N$ & $8.33^{* * *}$ & $8.72^{* * *}$ \\
\hline
\end{tabular}

Source: Swiss Household Panel, 1999-2017. 
Table A5 Changes of life satisfaction during old age. Fixed effects models with gender interaction terms

\begin{tabular}{|c|c|c|c|c|}
\hline \multirow[b]{2}{*}{ age } & \multicolumn{2}{|c|}{ Age $60-74$} & \multicolumn{2}{|c|}{ Age $75-89$} \\
\hline & -0.02 & $(0.01)$ & -0.03 & $(0.01)$ \\
\hline age $\times$ woman & 0.00 & $(0.01)$ & 0.02 & $(0.02)$ \\
\hline divorced at 60-64yo/75-79yo $\times$ age & 0.03 & $(0.03)$ & 0.02 & $(0.05)$ \\
\hline divorced at 60-64yo/75-79yo $\times$ age $\times$ woman & 0.02 & $(0.03)$ & -0.01 & $(0.06)$ \\
\hline widowed at 60-64yo/75-79yo $\times$ age & 0.03 & $(0.04)$ & 0.04 & $(0.05)$ \\
\hline widowed at 60-64yo/75-79yo $\times$ age $\times$ woman & -0.03 & $(0.05)$ & -0.02 & $(0.05)$ \\
\hline never married at 60-64yo/75-79yo × age & -0.03 & $(0.05)$ & -0.03 & $(0.01)$ \\
\hline never married at 60-64yo/75-79yo $\times$ age $\times$ woman & $0.19^{*}$ & $(0.09)$ & $-0.63^{* * *}$ & $(0.11)$ \\
\hline in nonmarital partnership $\times$ age & -0.03 & $(0.03)$ & -0.04 & $(0.03)$ \\
\hline in nonmarital partnership $\times$ age $\times$ woman & -0.01 & $(0.03)$ & 0.04 & $(0.05)$ \\
\hline childless $\times$ age & 0.00 & $(0.02)$ & -0.04 & $(0.04)$ \\
\hline childless $\times$ age $\times$ woman & -0.01 & $(0.03)$ & 0.01 & $(0.06)$ \\
\hline divorced at $60-64 y 0 / 75-79 y o \times$ childless $\times$ age & 0.07 & $(0.06)$ & $0.39^{* * *}$ & (0.06) \\
\hline divorced at $60-64 y 0 / 75-79 y o \times$ childless $\times$ age $\times$ woman & -0.08 & $(0.07)$ & $-0.52^{* * *}$ & (0.14) \\
\hline widowed at 60-64yo/75-79yo $\times$ childless $\times$ age & 0.08 & (0.05) & 0.00 & $(0.07)$ \\
\hline widowed at 60-64yo/75-79yo $\times$ childless $\times$ age $\times$ woman & 0.09 & $(0.11)$ & -0.03 & (0.09) \\
\hline never married at 60-64yo/75-79yo $\times$ childless $\times$ age & 0.10 & $(0.05)$ & 0.01 & (0.06) \\
\hline never married at 60-64yo/75-79yo $\times$ childless $\times$ age $\times$ woman & $-0.22^{*}$ & $(0.10)$ & $0.69^{* * *}$ & $(0.13)$ \\
\hline married $\rightarrow$ widowed & -0.16 & $(0.31)$ & -0.26 & $(0.28)$ \\
\hline married $\rightarrow$ widowed $\times$ childless & $-2.12^{* * *}$ & $(0.33)$ & $-1.07^{* *}$ & (0.36) \\
\hline married $\rightarrow$ widowed $\times$ woman & -0.26 & $(0.37)$ & 0.26 & $(0.32)$ \\
\hline married $\rightarrow$ widowed $\times$ childless $\times$ woman & $2.99 * * *$ & $(0.64)$ & 0.91 & $(0.50)$ \\
\hline married $\rightarrow$ divorced & -0.18 & $(0.61)$ & $-1.33^{* * *}$ & $(0.09)$ \\
\hline married $\rightarrow$ divorced $\times$ childless & -0.21 & (0.58) & - & - \\
\hline married $\rightarrow$ divorced $\times$ woman & -0.16 & (0.66) & $2.02^{* * *}$ & $(0.10)$ \\
\hline married $\rightarrow$ divorced $\times$ childless $\times$ woman & $2.46 * * *$ & (0.64) & - & - \\
\hline divorced $\rightarrow$ married & -0.22 & $(0.32)$ & - & - \\
\hline divorced $\rightarrow$ married $\times$ childless & $1.41^{* * *}$ & (0.33) & - & - \\
\hline divorced $\rightarrow$ married $\times$ woman & -0.04 & $(0.43)$ & - & - \\
\hline divorced $\rightarrow$ married $\times$ childless $\times$ woman & $-2.05^{* * *}$ & $(0.44)$ & - & - \\
\hline never married $\rightarrow$ married & -0.21 & $(0.18)$ & $0.69^{* * *}$ & $(0.00)$ \\
\hline never married $\rightarrow$ married $\times$ woman & 0.34 & $(0.25)$ & - & - \\
\hline formation of non-marital partnership & $0.65^{* *}$ & $(0.22)$ & 0.10 & $(0.23)$ \\
\hline formation of non-marital partnership $\times$ woman & 0.08 & $(0.28)$ & 0.34 & $(0.63)$ \\
\hline dissolution of non-marital partnership & $-0.52^{*}$ & $(0.23)$ & -0.28 & $(0.25)$ \\
\hline dissolution of non-marital partnership $\times$ woman & -0.19 & $(0.29)$ & 0.18 & $(0.47)$ \\
\hline
\end{tabular}

Continuation of table $A 5$ on the next page. 


\section{Continuation of table $A 5$.}

\begin{tabular}{|c|c|c|c|c|}
\hline & \multicolumn{2}{|c|}{ Age 60-74 } & \multicolumn{2}{|c|}{ Age $75-89$} \\
\hline lower education × age & -0.01 & $(0.01)$ & 0.01 & $(0.02)$ \\
\hline lower education $\times$ age $\times$ woman & -0.00 & $(0.02)$ & -0.01 & $(0.03)$ \\
\hline transition to retirement & 0.10 & $(0.05)$ & 0.10 & $(0.40)$ \\
\hline transition to retirement $\times$ woman & -0.11 & $(0.07)$ & -0.29 & (0.51) \\
\hline intercept & $8.22^{* \star *}$ & $(0.02)$ & $8.33^{* * *}$ & $(0.24)$ \\
\hline N & \multicolumn{2}{|c|}{13993} & \multicolumn{2}{|c|}{5057} \\
\hline $\mathrm{Nr}$ of individuals & \multicolumn{2}{|c|}{1642} & \multicolumn{2}{|c|}{641} \\
\hline
\end{tabular}

Source: Swiss Household Panel, 1999-2017. 